\title{
The Education Professionals Valuation and Formation Program - Proformar: An Amazonian Experience in Educational Public Policy
}

\author{
Caio Henrique Faustino da Silva ${ }^{1, *}$, André Luis Nunes Zogahib ${ }^{1}$ \& Bárbara Castro Lapa ${ }^{2}$ \\ ${ }^{1}$ Amazonas State University, UEA - Manaus, Amazonas, Brazil \\ ${ }^{2}$ Amazonas Federal Institute, IFAM - Manaus, Amazonas, Brazil \\ *Corresponding author: Amazonas State University, UEA - Manaus, Amazonas, Street D, \\ Block A. City: Manaus-Amazonas, ZIP code 69054-717, Brazil. E-mail: \\ chfsilva.ch@gmail.com
}

Received: February 24, 2015 Accepted: March 20, 2015 Published: April 10, 2015

doi:10.5296/ije.v7i2.7154 URL: http://dx.doi.org/10.5296/ije.v7i2.7154

\begin{abstract}
This study aims to understand the process of constructing deployed in the Education Professionals Valuation and Formation Program - Proformar held in the Amazonas province. The main motivation was to understand how an educational public policy was able to form more than 16000 teachers from the Amazon public school system in less than a decade. In order to identify the elements that contributed to the preparation and implementation of this policy a literature and documental review was performed. As the results, were confirmed the Proformar's importance for the elementary and secondary provincial education system. Besides this, were identified the necessity to overcome the classical public sector legalism and bureaucratic thinking. At the same time, were identified the importance of public and private organizations as the main performers in public policies. External elements were found in the genesis of this educational policy, such as requirements contained in international documents ratified by Brazil that determine degrees in areas related to education for all the teachers in public and private schools; and internal elements, such as the ability of consultation and coordination of state and out of state mechanisms in the development and implementation of this educational public policy as well as national education standards. Moreover, were identified a tetrahedral interaction educational method based on a blended learning system. Thus, we seek to contribute to the promotion of new studies and debates on educational public policy and teacher education in Amazon.
\end{abstract}

Keywords: Educational Public Policy, Teacher Training, Amazon Education 


\section{Introduction}

\subsection{The Amazon education in the colony period: a different path}

The Federative Republic of Brazil occupies the most part of the South American continent and according to the Brazilian Institute of Geography and Statistics the territory covers an area of $8515767049 \mathrm{~km}^{2}$ being the fifth largest country in the world. Amazonas is on the list of the federative states that composes the Brazilian republic. As province, Amazonas occupies an area of $1559159148 \mathrm{~km}^{2}$ (IBGE, 2010) in the central region of the Continental Amazon. The province of Amazonas is the largest among the 27 states (including the Federal District) and has a population of approximately 3483985 inhabitants (IBGE, 2013) distributed in 62 municipalities and the province capital is Manaus which has about 2020030 inhabitants. Due to the distance and difficult access the Amazon region wrote an educational history with different characteristics from the rest of Brazil. In the colonial period, were undertaken series of actions whose purpose were the acculturation of the native people through a policy of interethnic marriages and by the education and conversion of these peoples to Christianity (Sampaio, 2011).

By the XVI and XVII century the relationship between the Portuguese Empire and the Catholic Church - this last being mainly represented by the Company of Jesus - was the manifestation of social and cultural siege undertaken over the aboriginal peoples of the Iberian America. Catechesis was the main instrument by which the Holy Church representatives would act and had a pedagogical political character by inserting standards of a civilization that was intended to be implement in the New World as legitimate and hegemonic (Nolasco, 2008). Therefore, within the Portuguese conquest and domination program it is possible to assert that: during almost five centuries, there was a close symbiosis between education and catechesis in the colonization of Brazil. Indeed, the education rises as a phenomenon of acculturation having in catechesis his idea-force, which is firstly and clearly stated in the Rules of D. João III laid in 1549 and contained the guidelines to be followed and implemented in the Brazilian colony by the first general government. (Saviani, 2007).

\subsection{The Amazonas province education in the twentieth century}

However, over the past centuries little has changed. The elitist and domineering have been the main national and regional educational characteristic. Thus, after the Brazilian independence declaration from Portuguese ruled in 1822, it was possible to realize the obvious gap between a high quality education and the Amazon rainforest inhabitants. Despite the first national educational policies such as: the First Letters Schools, Training Colleges and the Education Institutes (Saviani, 2009) until the creation of the Federal University of Amazonas-UFAM in 1909, all the post-secondary studies should be conducted outside of the Amazon region and, normally, students with the best economical conditions were sent to European universities, especially the Iberian, like the University of Coimbra, Salamanca and Lisbon. In the early twentieth century, education in the Amazonas province was in its first steps. "The elementary school until the 50's was restricted to the municipal headquarters. School groups offered free public education, along with isolated multiple level schools in order to attend the educational demands" (Barbosa; Ramos, 2008). Briefly, that was the education provincial scenario until 
the mid-twentieth century.

In the 80's and 90's, the state experienced a growing movement towards the major regions of the country. Pushed a national economic policy based on the Manaus Free Zone Model, driven by the Manaus Free Zone Superintendence (SUFRAMA), Amazonas had a significant increase in their incoming. As a consequence of the new national plan for the Amazonas development, Manaus went through a complete transformation which could be seen when analysing the inhabitants rate before and after the Free Zone Model implementation (Nazareth, Brasil; Teixeira, 2011) (Andrade, 2012). Parri passu, the province was effectively included in the national decision-making political scene by being the recipient of national educational public policies. Regarding the education public policies, it is possible to point the Fund for the Maintenance and Development of Fundamental Education and Valorization of Teachers-Fundef (later replaced by The Fund for the Maintenance and Development of Basic Education and Enhancement of Education Professionals (Fundeb) and the National Fund for Education Development (FNDE). At the same time through the Education Provincial Plan 1990-1994, the Amazonas government created a set of (eminently assistance nature) programs among which is worth mentioning: The Administrative, technical, specialist and Teachers Valorization Program (Bezerra, 1998).

\section{Proformar and the Education in the Amazonas State}

\subsection{A teacher formation public policy and its agenda formation and elaboration.}

Accordingly, this was the scenario in which the Education Professionals Valuation and Formation Program - Proformar was inserted. The program grew out based on a request from the Education Provincial Department (SEDUC-AM) addressed to the newly created Amazonas State University - UEA and its main purpose regarded the World Declaration on Education for All 1990 and the 9.934 Brazilian Federal Act (1996) also known as the Guidelines and Bases of Education Act - LDB that establish as a basic principle, the educational quality standards guarantee and underline the necessity to improve the regular basic education by investing on the teacher's formation.

Therefore, was set the Proformar's main objective: promote the quality of regular public education in the Amazonas through direct investments in the education and training of education professionals. The creation of the program rests on the fact that Brazil has a great diversity and it is difficult to think of a policy that meets the Amazon to Rio Grande do Sul (Gatti, 2006). Thus, having as basis the determinations contained in National Education Act, once initiated the Decade of Education (1996-2006) the Federal Government and the provinces had to "conduct training programs for all practicing teachers also using, distance learning technology" (Brasil, 1996). Despite of the apparent ambition of such determinations, it is imperative to consider that the fourth paragraph of the same article stated that "By the end of the Decade of Education will be admitted only qualified teachers at the college level or formed by in-service training" was eventually repealed by the law 12796 published in 2013.

In order to develop and implement the Proformar, the Amazonas State University (UEA) 
hired Getúlio Vargas Foundation (FGV) to rely on the expertise of this institution in the management and coordination process of technical staff in: educational technology, TV production and logistics crew. (Barbosa, Ramos, 2008). After a series of feasibility studies developed by both directly involved institutions (UEA and ISAE / FGV) was decided to adopt as a means of disseminating their content the classroom learning mediated by TV, in other words, through a blended learning system (Nacol, 2012). This choice aimed to overcome the problems and difficulties that were shown from the beginning and which will be discussed later.

Table 1. Proformar: challenges as solutions

\begin{tabular}{|c|c|}
\hline Challenges & Solutions \\
\hline $\begin{array}{l}\text { To train teachers to work in the first stage } \\
\text { of Elementary Education and Early } \\
\text { Childhood Education in the publicly } \\
\text { funded schools. }\end{array}$ & $\begin{array}{l}\text { Partnerships with federal and state university } \\
\text { degrees that have headquarters in these } \\
\text { locations. }\end{array}$ \\
\hline Teachers' continuing education. & $\begin{array}{l}\text { Further training and expertise, eg .: Training } \\
\text { Program for School Managers, specialization } \\
\text { courses in Early Childhood Education, } \\
\text { Inclusive Education, Youth and Adult } \\
\text { Education. }\end{array}$ \\
\hline $\begin{array}{l}\text { To promote the training of Aboriginal } \\
\text { teachers respecting the strengthening of } \\
\text { culture and values of each ethnic group }\end{array}$ & $\begin{array}{l}\text { Pira-Yawara project that formed Aborginal } \\
\text { teachers able to teach classes in elementary } \\
\text { level, and has trained technicians from } \\
\text { municipal departments to work in secondary } \\
\text { schools. }\end{array}$ \\
\hline $\begin{array}{l}\text { Establish partnerships between the state } \\
\text { and municipal agencies }\end{array}$ & $\begin{array}{l}\text { Initial or continuing vocational teachers } \\
\text { training to Aboriginal and non-aboriginal } \\
\text { education. }\end{array}$ \\
\hline
\end{tabular}

Despite the fact that Proformar has faced several challenges in the province capital, the great distances between cities could be outlined as an issue that compound a problematic regional scenario. In this context, stands out as challenge the establishment of partnerships between the state Department of Education, the Federal and State universities and municipal governments served by Proformar. For instance, regarding the main challenges and strategies displayed in the table above, was created the Pira-Yawara project that reached up to the first decade of 2000 about 43,017 students through aboriginal education teachers' education to teach in elementary and secondary school. 


\section{Methodology}

Throughout the study, which took place between May and December 2014, the literature review of works that deal with the Brazilian educational development process was carried out, as well as the history of education in the north of the country, specifically in the state of Amazonas. Special attention was paid to public policies on education concerning the formation of education professionals in the Amazon, materialized by the implementation and development of the Education Professionals Valuation and Formation Program - Proformar.

\section{Results of Research}

The Proformar was able to - in less than a decade and organized in two cycles (Proformar I and II) - transform the landscape of public education in the Amazonas State offering the undergraduation course in education for more than 16000 teachers. The program numbers of attended teachers, the duration and the amount of public resources (global and unit values) allocated in the program can be better visualized in the Figures 1, 2, 3, respectively.

In addition, this program provided an increasing of the academic research production within the following research lines: Education, Culture and Society; Art in School; Teaching; Learning Disabilities; School Failure and Leaning Assessments; Reading and Math Teaching. In complete numbers, over 16000 monographic studies were produced in the eight years of the Proformar by the undergraduated teachers.

Thus, the program final numbers are shown in the figure 1. This figure presents the number of teachers enrolled in the program in its two cycles. Initially, it was possible to extract the following conclusions:

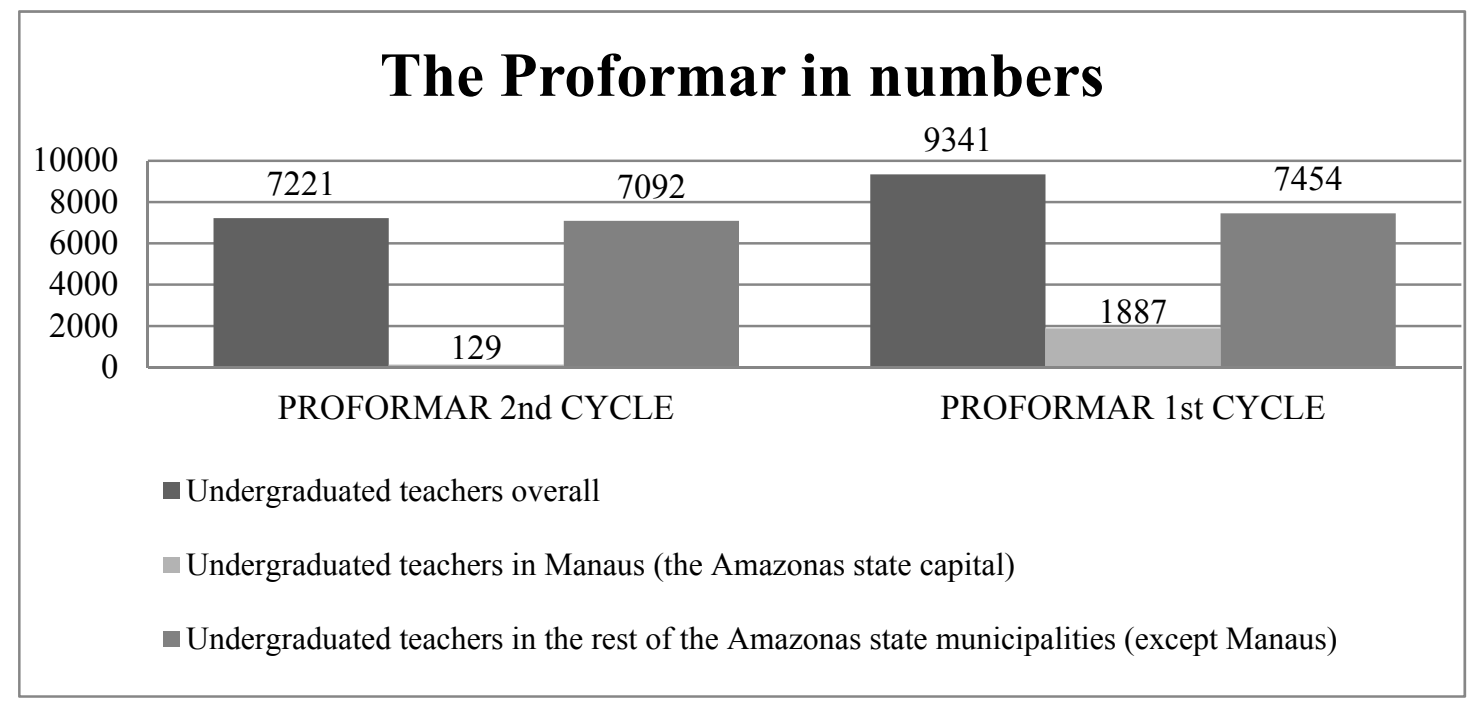

Cycles I and II were developed in the years 2001-2008.

Figure 1. Undergraduated teachers by Proformar 


\section{Macrothink}

- Proformar presented in the municipalities greater numbers than in the province capital;

- b) It is possible to see a considerable rise in the final numbers of the program if analyzed that Proformar, on its first cycle, was able to form 2000 more teachers than in its second cycle;

- c) and in the cycle II Proformar presented (in the capital) and lower numbers in comparison with first cycle data, nevertheless, the program presented (in cycle II) a significant growth related to the amount of formed teachers in the state municipalities (except the state capital, Manaus).

At the same time, Figure 2 shows a comparison between the overall amounts invested in the two cycles of the program. Here, you can observe a considerable decrease in investment numbers when comparing the two cycles. This reduction in overall investment is reflected in the fact that: in order to implement the program was necessary to build the entire infrastructure necessary for operation and management and in its second cycle all existing infrastructure was used.

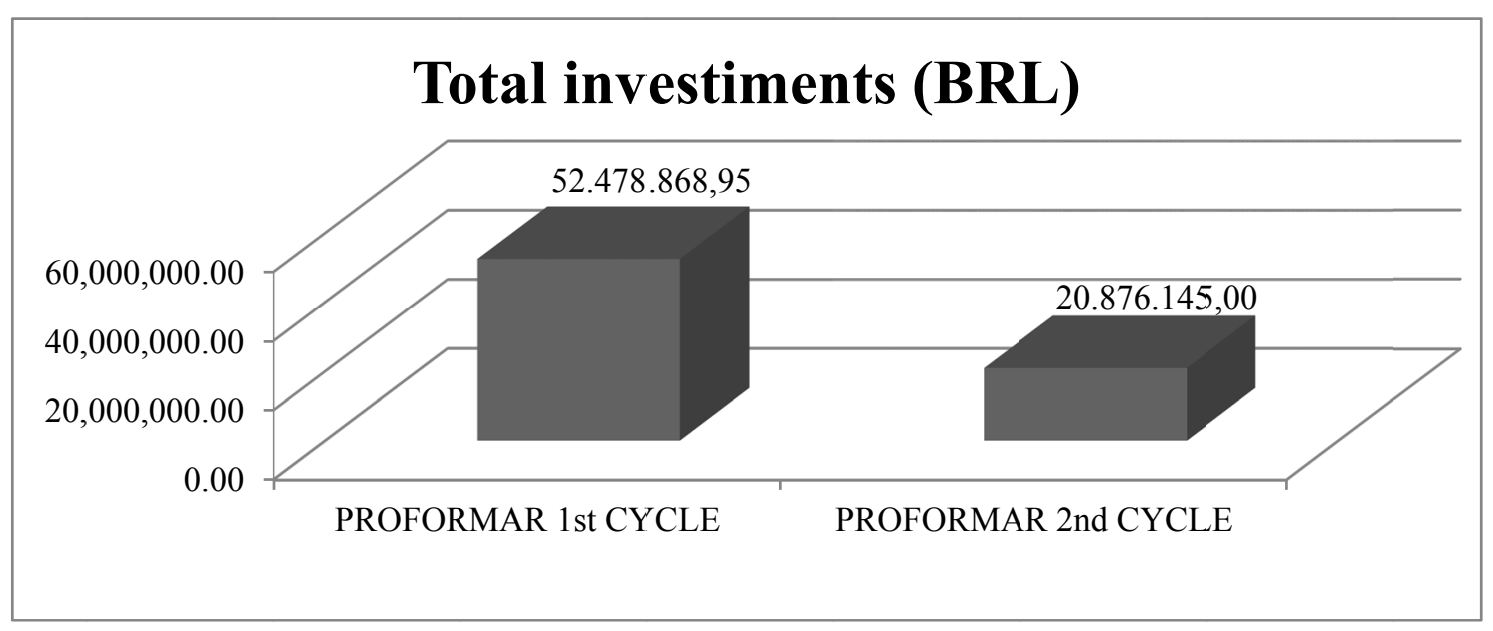

Figure 2. Comparison between the total investments in the two cycles of Proformar

The Figure 3 shows a comparison between the average amounts invested in the training of each teacher attended by the program. At this point, it was possible to figure the unit costs reduction which invariably followed the reduction occurred in the overall costs of the program in its second cycle. 


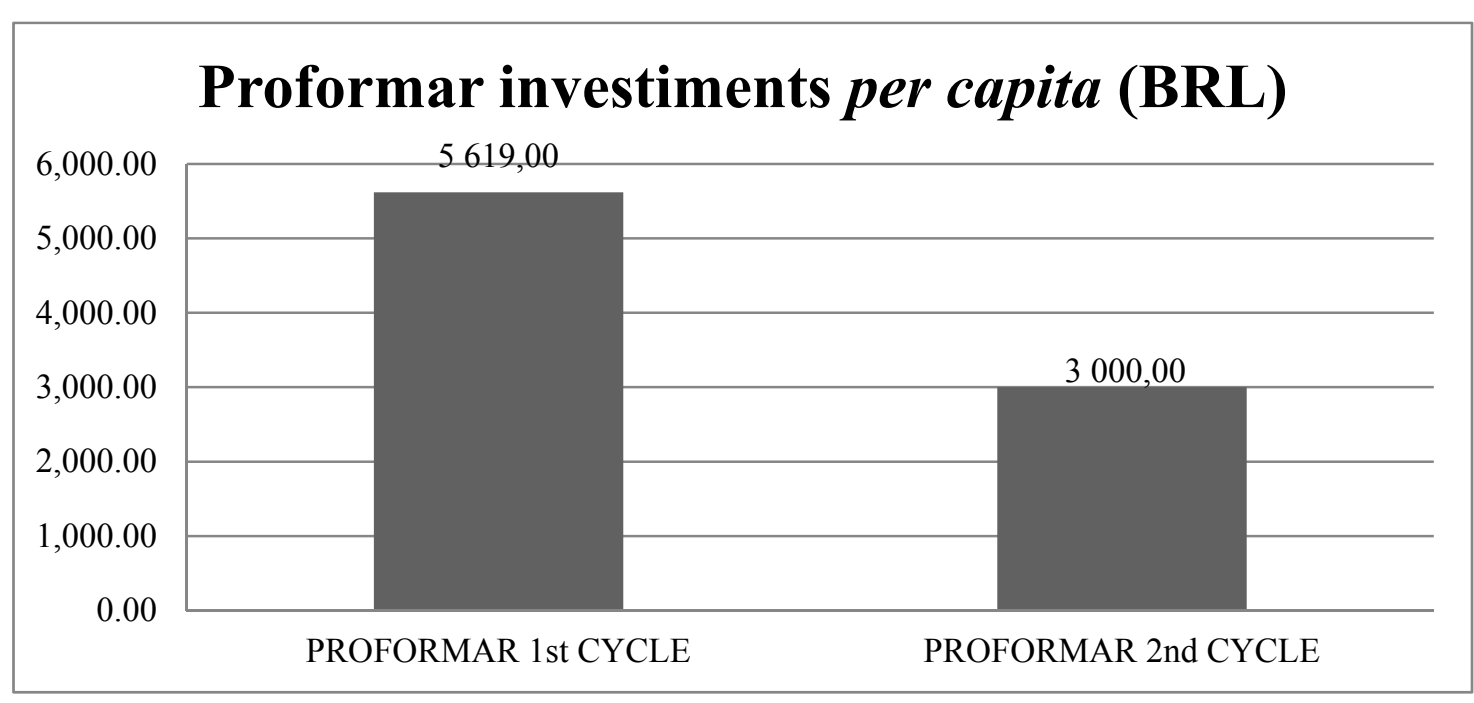

Figure 3. Comparison between investments in training of each student-teacher in cycles I and II

At the same time, it is possible to consider that since its conception the Proformar was surrounded by limitations that contributed to the increase of the program final costs in its first cycle such as:

- The large number of municipalities within the state of Amazonas;

- b) The long distances that separate municipalities;

- c) The lack of regular transport lines between locations, whose access was only possible by air at certain periods of the year;

- d) The irregularity and, in some cases, the inability to establish direct communication lines (telephone, TV and / or internet) between the capital and other cities in the province; etc.

Considering every public policy as an integrated set of governmental sectorial actions aiming the general welfare including different aspects and prioritizing in accordance with the action(s) urgency and relevance as well as the fact that public policies are influenced, from its incorporation to the cast of government agency initiatives, by the contingencies that affected the State dynamics (Saravia, 2006). Therefore, it is reliable to consider that the Proformar acted as an educational public policies locomotive undertaken in the Amazonas in the early years of the twenty-first century which can be clarified when considering the academic research production increase as a result of Proformar's initiatives in the following areas: Education, Culture and Society; Art in School; Teaching; Learning Disabilities; School Failure and Learning Assessment; Reading Teaching and Math Teaching. In overall numbers, over 16000 monographic studies were produced in the eight years of the Proformar by the undergraduated teachers.

Finally, considering the structure left by Proformar and the fact that other programs were implemented among which we can mention: the undergraduation course of Political Science, 
Mathematics, Technology Analysis and Systems Development, Physical Education and Specialization in Educational Management and also based on the infrastructure delivered by program, the first public post-secondary preparatory course in order to support more than 250 000 students in the State University entrance exams as a partnership between the Amazonas State University and the Amazonas government.

\section{Discussions}

Preliminarily, it is necessary to consider the capacity of cooperation and coordination existing between public institutions and private organizations in order to make possible the implementation of an educational program of this significance. It becomes clear when this investigation realizes that: due to established commitments - in international instruments and Federal Law - the state was mobilized through an inner transformation of the legal system and the regional education structure in order to facilitate the fulfillment of the obligations contracted.

Table 2. Program partnership

Institutions/Organizations

SEDUC

UEA

FGV/ISAE

Fundação de Apoio Institucional Muraki
Actions

Proformar program applicant for the enforcement of the legal provisions in the Guidelines and Bases Education Law.

Supply of teaching staff, administrative and support the production and printing materials.

Coordination of Educational Technology teams, TV Production, logistics, maintenance and management of image transmission studios and sound.

Financial administration of the program, hiring human resources needed to the program and system maintenance.

By the same time, were identified the concerted actions inside the provincial infrastructure by the creation of an university and by assigning its responsibility that matches with the purpose for which was created: to offer the higher education in all over the province (the capital and in others 15 municipalities). Whereas the joint occurred through the Education Department (SEDUC-AM) which already had an operational structure in all 62 provincial municipalities by the direct interaction with the political power of each location (herein the Municipalities and their Education Departments). 
Here, remains to consider the region complexity that shapes the reality of the people of the Amazon region and the Amazonas state in which 15 of the 61 state municipalities (except the capital) are at distances greater than $800 \mathrm{~km}$ (in straight line) starting from the capital. In this case, there are municipalities in excess of $1000 \mathrm{~km}$ distances, which should covered by the main means of intercity transportation in the region, the regional boats(Note 1).

Considering the network of the main means of transportation existing in the north region: only the states of Pará, Amapá and Tocantins have railways in operation (in particular the north-south railroad that crosses the State of Tocantins, which is used as a cargo transportation line). Great part of the federal and provincial roads are unduplicated and considerable portions still without proper pavement; a set of mostly river with small harbors except in big cities such as Manaus, Macapa, Marajó Island and two other near Belém-PA (Transport, 2002). Therefore, it is possible to realize that in the north region, and especially in the Amazonas, mobility difficulties still imposing harsh conditions that deeply hamper the implementation and execution of public policies developed in the national, regional and local level.

In this field, with the difficulties faced by the program, it was noted that the provincial Government through the Departament of Education and the Amazonas State University offered to the municipalities an adaptable program to different realities and difficulties faced by these locations. In these localities, the Proformar promoted a transformation in the way of thinking the learning environment. In this program, the environment of the student-teacher learning exerts considerable impact on the parts effectiveness in the system controlled by the University (Moore and Kearsley, 2011). For instance, in locations where the population is largely indigenous, specialized centers were created in indigenous education and in native teachers' formation (in the cities of São Gabriel da Cachoeira, Santa Isabel do Rio Negro and Tabatinga).

\section{Conclusions}

Initially, were recognized the possibility to understand the program from different points and varying angles. And, based on this, it is feasible to say that the purpose of this study was never exhaust the subject by means of a technical and restricted analysis based on the fact that in the "countries of Latin culture, the legal perspective maintains its own legalism rooted in the conformation of their state systems effectiveness." (Saravia, 2006). In contrast, Proformar was glimpsed as a reflection of a political, economic and social conjecture. By revisiting the country and especially of the Amazon region historical background was discovered how events of different orders, facts and decisions that threads of our history are intimately connected. At the same time, this research was guided by the "concern for getting more knowledge about the general characteristics of political systems and the relationships between public policies and politics as well as government and society." (Saravia, 2006).

So, was seen through a program of considerable importance, how several actors move into a complex game of political and economic relations. Was identified how the state and its 
different levels of power (the State in its contemporary meaning and, in the Brazilian case, formed by the Federative Union, the Provinces and Municipalities) are directly connected in the formulation of their agendas, development and implementation of public policies, especially those of educational order. In other words, we realize that the government officers were involved creating the space - the relational field - which exists only through the agents that act there and altering the space around them, giving it a certain structure. (Bourdieu, 2006). In addition, as the institutions involved, it is possible to conclude "as nearly all public policies are implemented by big public organizations, only by understanding how organizations work we can understand how the policies are modeled in the implementation process." (Elmore, 1988).

Furthermore, we identified that, according to Bourdieu (2006), the weight of an agent depends on many factors that, when combined, form differential success factors that can secure a compared advantage to the other agents involved. We must also consider the impact of capital in all its forms - financial, technological, legal and organizational - in the composition of the relational set that led to the implementation of the program. In this way, it is possible to identify the financial, technological, legal and organizational capital always held by the public sector. However, this concentration of different types of capital was possible by the concertation, cooperation and coordination capacities of this agent. For example, if we analyze that neither the Amazonas Government nor its secretariats initially had the knowledge (as technical abilities) necessary for the Proformar development, implementation and execution and they transferred the program conduction for the newly created State University after that this organization decided to hire an already consolidated company to help in its mission.

At the same time, was possible to realize the importance and the power that the international documents and instruments are able to influence the political and economic environment on developing countries. Such statement is clarified when considering the commitments made by Brazil in international organizations - such as the United Nations (UN) and UNESCO (eg. UNDP-MDGs and the Jomtien conference, respectively) - and how their determinations are embodied in national regulatory instruments among which can be highlighted: the Constitution of the Federative Republic of Brazil from 1988 (which booked an entire chapter to the subject, education) and the Directives and Bases of education Act (LDB). However, the importance of such normative legal instruments, the tendency of bureaucratic national state cannot be forgotten (Gatti, 2006) as the result of a conservative ultra-liberal reform (Bourdieu, 2006) that still present in the Brazilian political scenario.

However, it is also imperative to overcome such paradigms in order to improve the state and its functions. Thus, by the government policies, replacing the government by law, assumes the combined exercise of several tasks that the liberal state completely unaware. Supposes lifting accurate information about the national and global reality, not only in quantitative terms), but also on facts not reducible to numbers, as in education, inventiveness and quality life (Comparato, 1989).

By its turn, we must consider that the needs, preferences and propensities are not only 
exogenous, based on global relation and standards, but also endogenous and dependent on the history, which is precisely the cosmos where they are required and rewarded (Bourdieu, 2006) therefore, the public policies, and especially the educational ones, should be designed based on the local and regional needs and reality. Furthermore, it is feasible to affirm that no training ensures a high level and complete education by itself. Every professional needs further training in the workplace if it is possible (Gatti, 2006) and, at the same time, adequate infrastructure and availability of pedagogical material (Barbosa, 2007).

Were also noticed that Proformar was able to promote a tetrahedral interaction between student, content, teacher and instructor, thus surpassing the generally imposed on educational initiatives in distance education interactive limits (Moore and Kearsley, 2011). And at the same time the program was able to change the access to information (reached the more than 60 existing locations in the state of Amazonas); changed the relationship between knowledge and economic development (provided the improvement in the students education quality through theoretical and practical training led to teachers of municipal and provincial elementary and secondary public school systems); changes in learning objects (due to the necessity of adapting the Proformar different realities and difficulties found in the Amazon region).

Finally, was recognized the need to encourage and promote the participation of civil society in the design, development and implementation of this type of public policy process, originally assigned to the State. This mission, can be accomplished through the movement of empowerment the institutionalized forums and by overcoming the dichotomy between civil society and the State (Bobbio, 1986). This work also aims the possibility to expose to the world an Amazon experience in teacher training, its impact and after that encourage and contribute to the promotion of debates and the exchange of experiences on a topic that is far from to be exhausted and that continually raises questions able to trigger new studies.

\section{Acknowledgement and Sponsoring information}

This research is granted by the Amazonas Research Support Foundation - Fapeam by the Scientific Research Program.

\section{References}

Andrade, Aldair Oliveira. (2012). Migrações para Manaus e seus reflexos socioambientais. Revista Somalu, 12(2), Jul/dez, 2012.

Barbosa, Walmir Albuquerque \& Ramos, José Ademir Gomes. (2008). Proformar e educação no Amazonas. Manaus: Valer.

Barbosa, Walmir Albuquerque. (2008). Proformar: políticas públicas e educação. Manaus: UEA edições.

Bezerra, Adenice Alves. (1998). As políticas para escola pública no Amazonas (1987/1994): 
Da ênfase na democracia à meta da eficiência. Universidade Estatual de Campinas.

Bobbio, Norberto. (1986). Estado, Governo e Sociedade para uma teoria geral da política. São Paulo: Paz e Terra.

Bourdieu, Pierre. (2006). As estruturas sociais da economia. Porto: Campo das letras.

Brasil, Congresso Federal. Lei no 9.394, de 20 de dezembro de 1996. Lei de Diretrizes e Bases da Educação Nacional.

Comparato, Fábio Konder. (1989). Para viver a democracia. São Paulo: Brasiliense.

Elmore, R. (1978). Organizational models of social program implementation. Public Policy num, 26.

Estatística, Instituto Brasileiro de Geografia. Contas regionais do Brasil 2010. Retrieved June 24, 2014 from ftp://ftp.ibge.gov.br/Contas_Regionais/2010/pdf/tab01.pdf

Estatística, Instituto Brasileiro de Geografia. Sinopse do censo demográfico 2010. Retrieved June 24, $2014 \quad$ from http://www.censo2010.ibge.gov.br/sinopse/index.php?dados=21\&uf=13

Gatti, Bernardete. (2006). Difusão de Ideias. São Paulo: Fundação Carlos Chagas.

Learning, North American Concil of Online. (2012). Blended Learning: The Convergence of Online and Face-to-Face Education.

Moore, Michael \& Kearsley, Greg. (2011). Educação a distancia: uma visão integrada. São Paulo: Cengage Learning.

Municípios, Associação Amazonense. (2010). Distancia dos municípios em relação a capital Manaus. Confederação Nacional de Municípios. Retrieved October 7, 2014 from http://portal.cnm.org.br/sites/8100/8133/Distancia_dos_Municipios_em_relacao_a_cap. pdf

Nolasco, Patrícia Carmello. (2008). A educação jesuítica no Brasil colonial e a pedagogia de Anchieta: catequese e dominação. São Paulo: Universidade Estadual de Campinas.

Sampaio, Paloma Maria Melo. (2011). Espelhos partidos: etnia, legislação e desigualdade na colônia. Manaus: Editora da Universidade Federal do Amazonas.

Saviani, Demerval. (2007). História das ideias pedagógicas no Brasil. São Paulo: Campinas. (2009). Formação de professores: aspectos históricos e teóricos do problema no contexto brasileiro. Revista brasileira de Educação, 40(1), 143-155.

Smith, Anthony. (1994). Os conquistadores do Amazonas: quatro séculos de exploração e aventura no maior rio do mundo. São Paulo: Best Seller.

Tayana Nazareth, Marília Brasil \& Pery Teixeira. (2011). Manaus: crescimento populacional e migrações nos anos 1990. Revista Paranaense de Desenvolvimento, 201-217. 


\section{Macrothink}

International Journal of Education

ISSN 1948-5476

2015, Vol. 7, No. 2

Transportes, Ministério dos. Banco de informações e mapas dos transportes-BIT. (2012) Retrieved July 24, 2014 from http://www2.transportes.gov.br/bit/

Note

Note 1. This regional term refers to the popular wood boats used in the whole Amazon region as the main mean of transportation between the Amazon cities and locations.

\section{Copyright Disclaimer}

Copyright for this article is retained by the author(s), with first publication rights granted to the journal.

This is an open-access article distributed under the terms and conditions of the Creative Commons Attribution license (http://creativecommons.org/licenses/by/3.0/). 